\title{
KARAKTERISTIK MISI KELUARGA DALAM PERSPEKTIF PERJANJIAN LAMA
}

\author{
Gernaida Krisna R. Pakpahan \\ Sekolah Tinggi Teologi Bethel Indonesia \\ Jl. Petamburan IV No.5 Jakarta Pusat \\ E-mail: gernaida@gmail.com
}

Diterima tanggal: 09 Juni 2020

Dipublikasikan tanggal: 26 Juni 2020

\begin{abstract}
ABSTRAK
Menurut penelitian Barna, bahwa 51\% orang percaya tidak memahami Amanat Agung, padahal orang percaya dipanggil untuk melaksanakan tugas tersebut dalam dunia ini. Gereja melayani umat Allah dan membangun komunitas yang menyaksikan dan merasakan kehadiran Kristus. Untuk memahami tugas dan panggilan ini, maka perlu dipahami tugas bangsa Israel yang juga mengandung aspek misi dalam Perjanjian Lama. Pemilihan dan pemanggilan bangsa Israel menjadi umat Allah berarti juga mengandung tugas di dalamnya, yaitu menjalankan misi Allah atas dunia. Sejak kehidupan Adam hingga bangsa Israel, Allah memberikan mandat untuk menjadi berkat bagi dunia. Oleh karena itu, dalam penelitian ini akan dibahas mengenai panggilan dan misi Allah dalam Perjanjian Lama. Setiap tokoh dalam Perjanjian Lama memiliki panggilannya masing-masing untuk menjalankan misi Allah sebagai tujuan hidupnya. Dengan menganalisa semua tokoh tersebut, terlihat kesamaan yaitu membawa orang lain/bangsa lain untuk terhisab sebagai umat Allah. Dimana dalam hal ini, umat Allah harus hidup dalam kekudusan Allah.
\end{abstract}

Kata kunci: misi, perjanjian, berkat, kerajaan

\begin{abstract}
According to Barna's research, $51 \%$ of the church did not understand the Great Commission. Though the church is called to carry out its witnessing duties in this world. The church serves God's people and builds communities that witness and feel the presence of Christ. In order to understand this calling, it is necessary to study the role of Israelites which also had the mission aspect in the Old Testament. The election of Israel as the people of God means that they also have a mission, as an agent of God's mission to the world. This concept can be seen within the history of the life of Adam until the people of Israel, where God had given the mandate to become a blessing for the world. This research then will elaborate the calling and mission concept within the Old Testament, especially the chosen characters in it. In that context, every character in the Old Testament had their own calling to do God's mission as their life goal. They all have the same characteristic that is their life goal is to bring other or people to enjoy the blessing of God as God's people. In that way, the people of God will live in his holiness.
\end{abstract}

Keywords: mission, covenants, blessings, kingdom 


\section{PENDAHULUAN}

Gereja hadir di dunia yang selalu mengalami perubahan yang disebabkan oleh perkembangan pengetahuan, teknologi, dan kemajuan peradaban manusia. Namun perubahan juga terjadi akibat dari suatu keadaan tertentu, misalnya perang, wabah, dan bencana alam. Perubahan dapat membawa dampak positif dan negatif yang sangat tergantung pada respon manusia, yaitu perilaku sosial dan budaya, gaya hidup, sikap terhadap diri dan sesama bahkan termasuk respon terhadap keyakinannya.

Saat ini, dunia berubah akibat pandemi covid-19 menjadi dunia new normal (kenormalan baru). Budaya baru seperti menjaga jarak satu dengan yang lain (physical distancing), memakai masker, mencuci tangan, bekerja di rumah (work from home), tinggal di rumah (stay at home) dan hal lainnya. Gereja dan pelayanannya pun harus beradaptasi dengan perubahan itu. Penyelenggaraan ibadah yang selama ini menggunakan upacara liturgi offline berkumpul di gedung gereja, kini menjadi ibadah online atau live streaming di rumah. Dalam konteks inilah gereja perlu meninjau ulang bentuk dan wujud pelayanannya termasuk doktrin ekklesiologinya. Kepekaan dan tindakan antisipatif gereja dalam mengadaptasi perubahan itu akan membantunya melaksanakan tugas dan panggilannya agar dapat tetap melaksanakan misinya dengan baik.

Hakikat kehadiran gereja dalam dunia adalah menjadi garam dan terang bagi dunia (Mat. 5:13-14). Perwujudan tugas dan panggilan gereja itu dihadirkan dalam pelayanan pastoralia (penggembalaan), koinonia (persekutuan), diakonia (pelayanan kasih), didaskalia (pemuridan), dan marturia (penginjilan). Keseimbangan tugas pelayanan gereja sebagai media berkat rohani dan pemenuhan kebutuhan yang bersifat jasmani sangatlah penting, supaya dapat mengubah dan membangun komunitas.

Kehadiran gereja untuk melayani sesamanya merupakan perwujudan kasih Kristus yang nyata kepada dunia. Pelayanan tugas marturia dinyatakan dalam misi dan kesaksian. Misi yang didasarkan pada kerinduan hati Tuhan sendiri yaitu agar keselamatan dinyatakan kepada dunia (Yoh. 3:16; Kis. 4:12). Pengutusan murid untuk memberitakan Injil ke seluruh dunia, membaptis, dan mengajar mereka untuk melakukan kehendakNya (Mat. 28:18-20) merupakan penegasan terhadap pelaksanaan 
misi yang dimaksud. Dalam hal ini gereja sebagai agen pelaksana Amanat Agung Tuhan.

Untuk memperoleh gambaran tentang pemahaman jemaat terhadap tugas pelaksanaan Amanat Agung itu, sebagaimana ditugaskan Yesus kepada para murid maka ada baiknya memperhatikan beberapa hasil temuan berikut. Hasil riset Barna (George Barna, 2018) yang dilakukan melalui survey terhadap gereja-gereja di Amerika, apakah jemaat memahami istilah Amanat Agung seperti yang ditemukan dalam Alkitab. Hasil temuannya cukup mengejutkan yakni 51\% jemaat tidak pernah mendengar istilah Amanat Agung; 25\% mendengar namun tidak memiliki pengertian yang jelas; hanya $17 \%$ yang memiliki mengerti dengan jelas; dan 6\% tidak meyakininya. Selanjutnya untuk memotret keadaan gereja di Indonesia maka perlu disimak hasil riset dari Riset Bilangan Center. Untuk mengetahui bagaimana pemahaman gereja terhadap Amanat Agung dalam Matius 28:18-20. Hasil temuan yang diperoleh antara lain: jemaat yang sangat memahami Amanat Agung sebayak 46.5\% ; lalu sebanyak $38.2 \%$ sedikit paham, $10.4 \%$ pernah mendengar tetapi tidak memahaminya, dan $4.8 \%$ tidak pernah mendengarnya. Masih dalam kaitan pelaksanaan tugas gereja, keprihatian Thomas Pentury (Pentury, 2019) sebagaimana dikutip dari hasil riset Bilangan Center, bahwa 50\% generasi milenial meninggalkan gereja. Datadata di atas memperlihatkan bahwa gereja dalam melaksanakan tugas marturianya untuk melaksanakan Amanat Agung masih jauh dari apa yang diharapkan.

Titik awal sarana misi Allah adalah keluarga sebagai instrumen penting dalam pelaksanaan misi dan bagian integral dari Gereja. Keberhasilan pelaksanaan amanat agung sangat ditentukan oleh keterlibatan keluarga, sehingga tata kelola keluarga yang Alkitabiah sangat penting. Menurut data dari biro sensus Amerika ada perubahan yang sangat signifikan dalam tata kelola keluarga dari tahun 40an, 50an dan 60an dimana 70 \% keluarga masih menerapkan pola tradisional. Hasil riset pada tahun 1994 menunjukkan bahwa 51\% anak-anak masih tinggal bersama keluarga utuh. Sebanyak 32 juta hidup dengan orang tua tunggal, atau orang tua tiri, saudara tiri. Kemungkinan besar juga anak-anak akan tumbuh dalam keluarga yang belum menikah.(Haddon A. Haynes, 1994) Hal ini merupakan realitas keluarga saat ini. Adanya perubahan budaya masyarakat turut pula mempengaruhi keluarga Kristen yang juga diperhadapkan pada fakta semakin meningkatnya angka perceraian, kecenderungan orang tua tunggal, anak 
dititipkan di keluarga karena alasan ekonomi dan masih banyak masalah lainnya. Hal ini akan menjadi tantangan tersendiri dalam menjalankan tugas marturia atau kesaksian sebagai implementasi amanat agung.

Prinsip yang digunakan untuk pelaksanaan amanat agung adalah kesaksian atau berita yang tertulis di dalam Alkitab. Sehingga pemahaman yang benar dan komprehensif terhadap Alkitab merupakan kebutuhan yang sangat penting. Pada umumnya Perjanjian Baru mendominasi isu-isu mengenai misi. Penggunaan kata ekklesia bagi gereja dari (Yun. Ek, "keluar dari" dan kaleo, "memanggil”, juga mempunyai arti "sidang rakyat". Sebagai "sidang rakyat", ekklesia dikonstitusikan oleh manusia, namun dalam Alkitab sebagai sesuatu yang vertikal yang dikonstitusikan Allah. Sidang itu tidak berhimpun atas keputusan sendiri, melainkan Allah sendiri yang menghimpun dan memanggilnya sehingga disebut jemaatNya. Kata ekklesia ini berarti mereka yang dipanggil keluar yaitu orang-orang merdeka berhimpun untuk menghadiri panggilan Allah (Roma 9: 24; Ef. 4: 1; II Tim. 9). Gereja adalah suatu persekutuan orang-orang yang menyadari, bahwa mereka adalah"orang-orang asing" di bumi (Ibr. 11: $8-16)$.

Misi pada hakikatnya bukan misi gereja, melainkan misi Allah sendiri, yaitu misi Allah Tritunggal; Bapa mengutus Kristus ke dalam dunia dan mengutus Roh Kudus untuk mendirikan jemaat; dan misi jemaat berdasarkan kematian dan kebangkitan Kristus (Ruck, 2011). Dalam Perjanjian Baru, secara hurufiah, kata "penginjilan” tidak ditemukan. Pada hakikatnya kata ini berasal dari bahasa Yunani

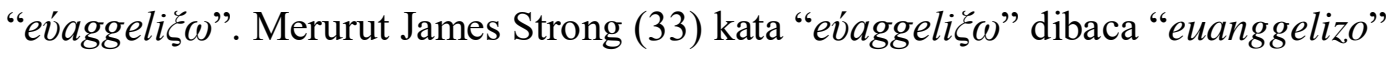
dapat diartikan mengumumkan, memberitakan, atau membawa kabar baik (Strong, 2007). Sedangkan kata "euanggelizo" menurut Horst Balz \& Gerhard Schneider (Balz, 2000) diartikan sebagai memproklamasikan Injil atau menjadi pembawa kabar baik di dalam Yesus.

Pemberitaan kabar baik itu adalah tugas orang percaya termasuk keluarga di dalamnya. Keterlibatan keluarga dalam melaksanakan misi tergambar jelas dalam keluarga Yesus sendiri. Yesus melaksanakan misi agung dari Bapa (Yoh. 3:16). Selain keluarga rasul-rasul, tampak pula adanya penginjilan di rumah-rumah sebagai salah satu pola pelayanan gereja mula-mula (KPR. 2). Salah satu contoh yang sangat baik 
mengenai peran keluarga dapat dilihat dalam keluarga Timotius, anak rohani Paulus. Jadi warisan iman merupakan hasil penginjilan yang dilakukan oleh neneknya Lois dan ibunya Eunike (2 Tim. 3-5). Karena itu, sahabat-sahabat Paulus pun menjadikan rumah sebagai sentral penginjilan mereka. Hal itu terlihat jelas pada keluarga Febe, Priskila dan Akwila, Maria, Andronikus dan Yunia, Trifena dan Trifosa dan yang lainnya (Rom. $16: 1-16)$.

Tentu saja, sudah ada berbagai kajian tentang penginjilan dan pelaksanaan amanat agung ditinjau dari aspek Perjanjian Baru. Karena itu, dalam penelitian ini, peneliti memfokuskan penelitiannya pada aspek misi dari Perjanjian Lama. Christhoper J. H Wright mengatakan bahwa "Misi umat Allah mesti diawali dan diakhiri dengan komitmen kepada Allah, sang pemilik misi yang didalamnya kita ikut serta oleh panggilanNya (Wright, 2013). Selanjutnya dikatakan bahwa umat Allah dipanggil untuk memiliki loyalitas yang tidak bisa ditawar-tawar dan tanpa kompromi kepada keunikan Allah - yang diwahyukan sebagai YHWH di PL, dan berjalan di tengah kita melalui kehidupan Yesus dari Nazaret dalam PB.

Menurut John Stott dan Johannes Verkyuil, "Jika dengan iman kita jadi milik Kristus, maka kita adalah anak-anak rohani Abraham dan memikul tanggung jawab untuk semua umat manusia” (John Stott, 2007). Keturunan Abraham tidaklah merujuk pada etnis keturunan tertentu atau hanya merujuk pada orang Israel pada masa Perjanjian Lama, namun lebih luas lagi yakni merujuk pada tiap orang dari segala bangsa (Gal 3:8-9 bnd 26-29). Orang-orang Kristen pada masa kini bukan merupakan keturunan Yahudi tetapi dapat disebut keturunan Abraham dan beroleh berkat melalui anak Allah yaitu Yesus sang Mesias. Para nabi PL juga telah mengatakan bagaimana Allah akan menjadikan sang Kristus ahli waris dan terang untuk bangsa-bangsa.

Agar penelitian ini lebih fokus maka perlu memperhatikan sejarah yang sudah diawali dengan pemanggilan umat Allah sebagaimana dikemukakan dalam Perjanjian Lama. Pemanggilan kepada individu seperti Nuh, Abraham, Musa juga pemanggilan Israel sebagai umat Allah memiliki tujuan dan misi khusus. Itulah sebabnya, cakupannya perlu dibatasi dalam beberapa pertanyaan berikut: Untuk apa Allah memilih umatNya di masa lampau? Peran penting apa yang dimiliki keluarga umat Allah dalam menuntaskan misinya? Apa misi yang diemban dalam pemanggilan Israel sebagai umat 
Allah? Pertanyaan-pertanyaan inilah yang berusaha dijawab melalui pemaparan berikut ini.

\section{METODE}

Pendekatan yang dilakukan dalam mengeksplorasi Perjanjian Lama adalah pendekatan kualitatif dengan metode kritik kanonik multikompleks. Pendekatan ini dikemukakan Gerhard F. Hasel (Gerhard F. Hasel, 1989) dengan beberapa kriteria. Namun dalam penelitian ini digunakan kriteria yaitu Teologi Perjanjian Lama disusun berdasarkan urutan sejarah yang berpusat pada berbagai tema, motif dan konsepsinya. Tema-tema longitudinal yang disajikan dari perjanjian Lama memiliki kesatuan yang dinamis dan mengikat satu dengan lain, meskipun muncul dari berbagai kitab. Selain itu, Teologi Perjanjian Lama dibangun atas kitab yang kanonik yang memiliki keterkaitan dengan sejarah atau sejarah agama Israel dan agama-agama di sekitarnya. Kemudian, struktur Teologi Perjanjian Lama juga mengikuti pendekatan multikompleks dimana konsep ini menolak konsep doktrin, menghindari hambatan dalam menyusun tema dan mengijinkan teologi - teologi berbagai kitab untuk maju bersama dan memberikan sumbangsih.

\section{HASIL DAN PEMBAHASAN}

Para ahli umumnya membangun dasar pijakan misi dari perspektif Perjanjian Baru. Hal itu didukung banyaknya teks yang terkait dengan misi. Sebaliknya dalam Perjanjian Lama tidak ditemukan adanya pengutusan umat Allah melintasi batasanbatasan geografis, keagamaan, sosial dan budaya untuk memenangkan orang lain kepada Yahwe.(David Bosch, 2006) Dalam kajiannya terhadap misi, Rezpkowski menganggap bahwa misilah yang memisahkan antara Perjanjian Lama dan Perjanjian Baru. Baginya kitab Yunus bukanlah sebuah kitab misi, yang oleh banyak ahli dianggap sebagai misi PL. Sama halnya dengan Hahn yang mengangap kitab Deutero-Yesaya sama sekali bukanlah kitab misi.

Dalam sebuah refleksi terhadap Perjanjian Baru sebagai dokumen misi, Bosch memberikan beberapa alasan penting mengenai posisi Perjanjian Lama yang terkait dengan misi.(David Bosch, 2006) Pertama, ada perbedaan yang menentukan antara iman Israel dengan agama-agama yang ada di sekitarnya. Agama-agama di sekitar Israel 
menyakini Allah hadir dalam alam kekal dan tempat-tempat kultik. Sementara Allah Israel, Allah sejarah yang aktif dalam karyaNya. Kedua, Allah adalah Allah perjanjian. Berbagai narasi yang terdapat dalam Perjanjian Lama memperlihatakan bahwa Allah mengikat perjanjian dengan umatNya sebagai berita yang dominan. Ketiga, Allah yang memilih Israel. Pemilihan Israel sebagai umat Allah memiliki tujuan khusus. Selain itu juga diyakini bahwa Allah dalam belaskasihNya mengasihi bangsa-bangsa.

Yakob Tomatala mengemukakan bahwa misi fokus pada Allah sebagai Pengutus, dimana Ia adalah sumber, inisiator, dinamisator, pelaksana dan penggenap misiNya.(Tomatala, 2003) Penekanan pada misi bersumber dari Allah, dengan demikian Allah sendirilah yang menjamin pelaksanaan misi itu. Dalam kekuasaanya, Allah sebagai inisiator misi yang secara kreatif akan membangun dan mengembangkan misi. Atas dasar itulah maka diyakini bahwa tidak ada hal apapun yang bisa membatasi atau menghalangi misi Allah secara permanen.

Sorotan yang lebih spesifik terhadap misi Alkitabiah terlihat dari karya Christopher Wright (Wright, 2007). Wright memberi perhatian besar terhadap misi yang dibangun atas Alkitab. Baginya Alkitab adalah dasar untuk memahami misi. Lebih tegas dikatakan bahwa Alkitab yang dihasilkan oleh dan/atau semuanya tentang misi Allah. Untuk itu diperlukan hermeneutik misi yaitu sebuah perfektif interpretatif yang selaras dengan misi besar itu. Wright memberi perspektif hermeneutis baru tentang Alkitab yang memberi dasar yang kuat untuk misi holistik. Misi holistik inilah yang dipandang sebagai bentuk misi yang tepat bagi gereja. Bahkan dapat dikatakan bahwa melalui misi holistik, Allah merebut kembali dunia dan umat Allah untuk ikut serta berperan aktif di dalamnya.

Selanjutnya dalam buku Misi Umat Allah, Wright menggunakan hermeneutik misi atas seluruh Alkitab (Wright, 2013). Fokusnya terhadap Alkitab kanonik yang membahas semua episode besar kisah Alkitab, termasuk semua doktrin besar iman alkitabiah, bersatu pada tokoh sentral Alkitab. Allah yang hidup telah merencanakan tujuan akbarNya atas seluruh ciptaan. Seluruh dunia adalah sasaran misi dan gereja bertugas untuk memberitakan Injil. Perlu disadari bahwa pemahaman khas Kristen tentang "misi" hanya mencakup sebagian kecil dari misi menyeluruh Tuhan untuk dunia. Tuhan tanpa henti mengklaim kembali seluruh dunia untuk diriNya sendiri. 
Gereja dipakai dan diarahkan Tuhan untuk menunjukkan betapa besar rencana Tuhan mengarahkan tujuan Allah dalam dunia.

Secara khusus, Walter Kaiser menyoroti misi dalam Perjanjian Lama. Misi dimulai dari rencana Allah sendiri (Walter C. Kaiser, 2000). Yang menjadi tujuan misi adalah keselamatan manusia. Pelaksanaan misi dimulai dari pemanggilan individuindividu guna dipakai sebagai alat untuk menyampaikan kabar baik kepada orang asing. Dalam skala yang lebih besar, Allah memilih Israel sebagai terang bagi bangsa-bangsa. Kaiser juga menggunakan model Yunus sebagai saksi bagi bangsa lain. Bahkan pemanggilan Paulus sebagai misionaris mengambil bentuk dari Perjanjian Lama.

Pemanggilan umat yang dikhususkan bagi Allah memiliki kemiripan baik dalam Perjanjian Lama maupun Perjanjian Baru. Dengan lugas Alkitab mengisahkan perkembangan sejarah umat Allah yang sekaligus pula merujuk pada perkembangan peradaban manusia. Narasi umat Allah itu digambarkan dalam kisah pemilihan, kejatuhan, penghukuman dan pembangunan kembali komunitas sebagai kisah-kisah yang tersaji di dalam sejarah. Keseluruhannya menggambarkan misi Allah bagi dunia, dan bagaimana umat pilihan itu berpartisipasi di dalamnya. Beberapa kisah yang cukup menonjol dari pemanggilan individu, keluarga dan bangsa akan dipaparkan sebagai berikut:

\section{Mandat Adam Untuk Menguasai Bumi}

Walter Kaiser mengidentifikasi tiga hal penting dalam perjanjian Allah sebelum masa patriakhi, antara lain rencana janji Allah tentang keturunan (Walter C. Kaiser, 2000). Perjanjian yang kedua adalah Allah berdiam di kemah Sem, dan yang ketiga adalah perjanjian berkat kepada bangsa-bangsa. Rencana janji Tuhan yang pertama tentang keturunan terkait dengan penyelamatan yang dikerjakan Allah setelah kegagalan Adam dan Hawa (Kej. 3:15). Kisah penciptaan manusia secara istimewa, laki-laki dan perempuan diciptakan di dalam rupa dan gambarNya (Kej. 1:26-27). Allah menciptakan Adam, seorang manusia laki-laki (Im. 13:2) dan Hawa seorang perempuan. Manusia diciptakan dalam rupa dan gambar Allah, maka dalam diri manusia terdapat pencerminan sesuatu yang berkaitan dengan sifat dasar Allah. Sementara kata "rupa" demut digunakan untuk pola, bentuk, atau ukuran yang adalah sesuatu seperti Allah pada diri mereka (Menzies, 1998). Manusia sebagai "gambar Allah" memiliki 
kedudukan yang sangat istimewa dibandingkan dengan ciptaan-ciptaan yang lainnya, karena manusia memiliki suatu hubungan yang bersifat pribadi dengan-Nya.

Manusia ciptaan Allah itu dibentuk yasar, sama seperti seorang penjunan yang membuat periuk (Yes. 29:16; 49:5); tukang emas yang membuat patung (Yes. 44:9; Hab. 2:18) dan Allah yang membetuk berbagai hal seperti mata manusia (Mzm. 94:9) dan hati (Mzm. 33:15) dan membuat musim (Mzm. 74:17). Menurut John Davis Allah membentuk manusia dari suatu bahan khusus yaitu debu tanah, avar dama. Debu tanah menunjukkan kerendahan dan ketidakberdayaan manusia di hadapan Tuhan. Namun secara kontras disebutkan bahwa manusia adalah "mahkota ciptaan Allah". Hal ini menunjukkan keagungan dan kebesaran manusia atas ciptaan yang lain, dan sekaligus pula menunjukkan kebesaran Allah.

Adam diciptakan Allah untuk misi khusus yang terlihat dari mandat yang diperolehnya. Pertama, Adam diberi mandat prokreasi. Adam sebagai manusia atau laki-laki (Im. 13:2) bersekutu dengan Hawa isterinya (Merril F. Unger, 1980). Manusia itu diberi berkat khusus yakni mandat untuk berkembang biak dan bertambah banyak sehingga memenuhi bumi. Ungkapan "Allah memberkati mereka dinyatakan dalam kemampuan manusia untuk berkembang biak atau prokreasi (1 Taw. 26:5). Prokreasi adalah berkat Allah, sekaligus pula merupakan perintah Allah. Hal itu berarti bahwa pernikahan adalah sungguh-sungguh perintah Allah demikian juga halnya dengan mendapatkan keturunan.

Kedua, manusia juga diberi mandat menguasai bumi. Mandat ini disebut juga mandat penatalayanan atau mandat budaya (Ruck, 2011). Adam berkuasa atas ikan di laut dan burung di udara dan atas segala binatang yang merayap di bumi (Kej. 1:28). Mandat yang kedua ini dengan jelas menggambarkan besarnya wewenang dan otoritas manusia atas seluruh ciptaan. Otoritas menyebabkan manusia memperoleh penghormatan dan penghargaan yang lebih tinggi di antara ciptaan lainnya. Inilah yang menjadi alasan manusia dimampukan untuk menghormati dan menyembah penjunanNya. Panggilan untuk memerintah ini adalah suatu panggilan untuk memajukan peradaban dan mengatur kekuatan-kekuatan alam agar semua dalam harmon dan keteraturan. Misi yang universal terlihat dalam mandat yang dimiliki Adam (Erich Sauer, 2001). Mandat budaya juga diberikan kepada semua manusia melalui 
berbagai kegiatan organisasi sosial, politik, ekonomi, pemeliharaan lingkungan hidup, konservasi atau perlindungan satwa langka pembangunan sumberdaya alam dan sumberdaya manusia (Ruck, 2011).

Kegagalan Adam atas mandatnya. Adam tidak menggunakan mandat yang diterimanya dengan baik. Fakta dosa telah merusak rupa dan gambar Allah dalam dirinya. Manusia keliru menggunakan kehendaknya yang bebas. Kehendak bebas itu harus bertangungjawab bukan sewenang-wenang.(Wallace, 1997) Kekuasaan manusia terhadap ciptaan lain itu menjadi berkurang bahkan hilang sama sekali. Ciptaan yang seharusnya berada di bawah kendali otoritas manusia sekarang berbalik menjadi musuh manusia. Alam semesta tidak lagi terkontrol oleh manusia demikian juga dengan binatang telah menjadi seterunya. Setelah kejatuhan manusia itu, Allah merancang penebusanNya (Kej. 3:15).(Ruck, 2011) Dengan demikian, pemeliharaan Allah tetap berlangsung terhadap manusia, generasi dan kehidupannya.

\section{Nuh Mengemban Mandat Adam}

Pasca-penghukuman Allah atas bumi, melalui air bah, berakhir maka Allah dalam anugerahNya menyelamatkan Nuh beserta keluarganya. Nuh membentuk keluarga dan komunitas baru dengan tatanan masyarakat dan budaya baru. Misi Allah atas alam semesta tetap berlangsung sekalipun manusia yang dipilih-Nya itu gagal sebagai mitra Allah. Bila diteliti dengan seksama maka tampak mandat Allah kepada Nuh memiliki kesamaan dengan mandat yang diembankan Adam.

Menurut Eugene Merrill, Darrell L Bock pemanggilan Nuh menjadi kawan sekerja Allah, diwujudkan dalam pengikatan sebuah perjanjian (Merrill, 2015). Dalam perjanjian itu, Allah sendiri mempercayakan mandat kepada Nuh, mandat yang serupa dengan Adam untuk menguasai bumi dan berkembang biak. Dalam hal ini, Nuh pun melaksanakan tugasnya sebagai Adam kedua. Peristiwa air bah mengambarkan hukuman Allah atas dosa dunia ini, tetapi juga menunjukkan kasih karunia-Nya. Nuh dan keluarganya diselamatkan untuk mengadakan suatu permulaaan masyarakat yang baru. Tindakan Allah ini menunjukkan perbedaan yang sangat tegas mitos Mesopotamia, dimana dewa-dewa tidak berniat untuk menyelamatkan siapapun. Bahkan dewa yang memberitahukan akan adanya ancaman malapetaka kepada Atra-Hasis 
dianggap sebagai penghianat. Dengan demikian tampak bahwa penyelamatan Nuh sekaligus menjadi penyelamatan peradaban manusia.

Mandat menguasai bumi adalah tugas yang diemban manusia. Perjanjian Allah dengan Nuh untuk mewujudkan suatu pengelolaan kasih karunia dan panjang sabar yang berdaulat, yang ilahi dalam asal, pembukaan, peneguhan dan pemenuhannya (Walter C. Kaiser, 2004). Dalam Perjanjian ini Allah memberikan berbagai jaminan kepada Nuh yakni 1) Jaminan keturunan, yakni Sem, Ham dan Yafet (Kej. 9:1dan Kej.10). 2); Jaminan kehidupan, yang memperlihatkan perlindungan Allah atas manusia termasuk makanan (Kej.9:3-4). Manusia tidak lagi hanya makan sayur-sayuran tetapi telah diberi daging untuk dimakan. Namun darah tidak boleh dimakan karena mewakili kehidupan (Im.17:14). 3) Jaminan sebagai mitra Allah untuk mengelolah alam dimana manusia akan menaklukkan alam, binatang akan takut kepada manusia dan akan ada siklus alam. 4) Jaminan keamanan dimana Allah berjanji tidak lagi menghukum dengan air bah dan adanya jaminan terhadap nyawa manusia.

Sebagai administrator Kerajaan Allah, Nuh harus menjaga kekudusan hidup manusia. Allah memberikan nilai atas kehidupan manusia sejauh barangsiapa membunuh sesama manusia maka ia harus menebus dengan nyawanya sendiri. Allah memandang pembunuhan sebagai penyerangan kepada pribadiNya karena manusia diciptakan sesuai dengan gambar dan rupa Allah (Paul Enns, 2008). Akan tetapi, pengaruh dosa tidak dapat begitu saja dan hal ini dibuktikan dengan anak-anak Nuh sendiri berada jauh dari komitmen perjanjian itu.

Sejarah baru dalam peradaban manusia tampak dalam pembangunan menara Babel. Kekuatan akal budi, kecerdasan intelektual manusia, semangat komunitas jelas diperlihatkan Nimrod yang disebut sebagai gibbor atau "orang gagah perkasa" di zaman itu (Kej. 6:4). Nimrod orang gagah perkasa dan ternama memiliki motif lain yakni "mencari nama bagi mereka sendiri", dan supaya mereka "tidak terserak di bumi" (Kej. 11) (Tennent, 2010). Pembangunan itu mengindikasikan dengan jelas sifat pemberontak manusia. Sebab mandat prokreasi yang diemban manusia adalah "penuhilah bumi dan taklukkanlah itu" (Kej. 1:28). Namun, sebaliknya mereka membangun manara Babel "supaya tidak terserak". Peristiwa itu memperlihatkan sikap ketidakpercayaan mereka kepada janji Allah, yang tidak akan menghukum manusia 
kembali dengan air bah (Kej. 11). Melalui kekacauan bahasa, Allah menjatuhkan hukuman atas mereka yang menyebabkan rusaknya komunikasi di antara sesamanya. Melalui hukuman ini, Allah menetapkan batas-batas pada kemampuan manusia untuk bersatu dalam pemberontakan melawan Dia dengan menyebarkan mereka secara geografis dan mengacaukan bahasa mereka. Ini tidak hanya membatasi kemampuan manusia untuk bertindak dengan kekompakan, tetapi juga menyiapkan suasana untuk perubahan strategi Allah. Sekarang kasih karunia Allah dinyatakan dalam tekad-Nya untuk menyatakan diri kepada manusia melalui satu orang dalam keluarganya.

\section{Mandat Abraham Amanat Misi}

Cikal bakal umat Allah dalam Perjanjian Lama dinyatakan melalui pemanggilan bapa leluhur Israel Abraham. Bapa leluhur Israel itu merupakan migran dari kota Ur, di selatan Mesopotamia sekitar abad ke-20 sM (Barth, 1984). Pemilihan Abraham diikat dengan perjanjian Allah (Kej. 12:1-3). Dengan jalan itu, keselamatan kepada bangsabangsa melalui Abraham terwujud. Panggilan Abraham itu merupakan pengulangan janji dalam narasi Nuh dan keluarganya ketika bumi dipulihkan kembali dari air bah (Kej 9:1) (Greatness, 1990). Hal ini menyiratkan bahwa tugas dan panggilan manusia itu serupa dengan tugas dan panggilan Adam (Kej 1:28).

David Hinson melihat bahwa perintah Allah bagi Abraham keluar dari Ur, ditandai dengan "pemisahannya" dari sanak-saudara dan keluarganya lalu pergi ke negeri yang dijanjikan Tuhan Allah kepadanya (David Hinson, 2004). Pokok isi janji Allah baginya adalah menjadikan namanya mashyur, memberkatinya, dan keturunannya kelak menjadi bangsa yang besar. Dengan dimulainya tugas dan tanggung jawab yang baru itu, maka komunitas baru juga terbentuk, yaitu komunitas yang terhisab ke dalam perjanjian yang terikat dengan Tuhan Allah.(Tennent, 2010)

Menurut Timothy $\mathrm{C}$ Tennent ada tiga hal penting dalam perjanjian Abraham yakni, pertama, Allah adalah sumber dan inisiator misi. Kedua, bahwa Yahwe adalah Allah yang mengutus. Ketiga, hati Tuhan tertuju kepada bangsa-bangsa. Tampaklah bahwa misi Allah melalui Abraham sangat universal kepada bangsa-bangsa.

Penggenapan janji Allah kepada Abraham melalui sebuah proses panjang yang berlangsung dari generasi ke generasi. Keteguhan hati, kesabaran dan ketaatan Abraham 
membuktikan betapa besar pengorbanannya di tengah-tengah pengharapan akan kegenapan janji itu. Ujian bagi imannya sering timbul melalui kelaparan, ancaman bagi nyawanya, isterinya, bahkan anaknya sendiri (Kej. 20, 22). Seringkali penggenapan janji itu tampaknya sebuah imajinasi belaka (Ibr. 11:8-11). Apalagi dalam fakta sejarah keturunan Abraham menjadi budak di Mesir empat ratus tahun (Kel. 1-2). Misi Allah dalam keluarga Abraham terjadi melalui respon ketaatannya terhadap mandat yang diperolehnya. Berikut ini beberapa hal penting dalam ikatan perjanjian yang diikat Abraham dengan Allah.

\section{Mandat Untuk "pergilah"}

Pemanggilan Abraham melalui penyataan Allah, diawali dengan sebuah permintaan dalam bentuk perintah lekh lekha "pergilah" (Kej 12:1). Perintah "pergilah" merupakan bentuk imperative atau "perintah", berarti sebuah tugas yang harus diselesaikan. Menurut Kenneth. A. Mathews, Abraham diperintahkan "meninggalkan negeri," erets atau "from your country" yaitu tempat dimana ia tinggal dan berdiam.(Kenneth A. Matthews, 2005) Perintah selanjutnya adalah ia harus "meninggalkan sanak saudaranya" moledet atau from your people. Perintah untuk meninggalkan keluarga intinya yakni bapanya bet ab atau from your father's household bukanlah tugas yang mudah. Ia harus meninggalkan dan harus terpisah dari keluarga besarnya, suku, negerinya dan adat-istiadat budayanya. Abraham harus memulai hidup baru termasuk membuka padang-padang penggembalaan baru.(David Hinson, 2004)

Meredith G.Kline (2000:309-310) melihat bahwa panggilan untuk "pergi” itu tidak hanya sebatas terpisah dari sukunya secara sosial budaya dan geografis namun juga harus terpisah secara keagamaan dengan menjauhkan diri dari penyembahan berhala dengan tujuan untuk komitmen melayani Allah. Misi Abraham dan keluarganya itu harus diresponi secara positif. Itulah yang menjadi dasar baginya untuk memiliki iman yang teguh dan pengharapan yang ditawarkan dalam janji itu. Perintah merupakan deklarasi persyaratan dari fakta sebuah kehidupan yang terikat dengan perjanjian.

\section{Mandat Untuk "membuat bangsa yang besar"}

Berkat yang diperoleh Abraham dari pelaksanaan perintah itu adalah "Aku akan membuat engkau menjadi bangsa yang besar"; "Aku akan memberkati engkau”; “Aku 
akan membuat namamu masyhur"; dan "engkau akan menjadi berkat" (Kej. 12:1-3). Menjadi "bangsa yang besar $l^{e}$ goy gadol memiliki cakupan yang lebih luas 'am "umat." Di kemudian hari, keturunan Abraham menjadi goyim atau "bangsa-bangsa" (Kej. 10:5, $20,31,32)$.

Pengutusan Abraham untuk "menjadi bangsa besar," memiliki kesamaan dengan berkat yang diterima Nuh dan dimulainya penyebutan banyak bangsa goyim (Kej. 10). Berkat Abraham itu menunjuk kepada "kebesaran, keagungan, kejayaan, kemegahan." Kebesaran bersifat kualitatif yang kemudian diperluas dengan kuasa yang dimilikinya dalam bentuk kuantitas yakni jumlah keturunannya. Secara historis di jamannya, Abraham sudah dikenal sebagai orang besar dan kuat (Kej 18:18). Selain itu, Abraham juga sudah memiliki kekuatan dalam jumlah yang secara alami merupakan bagian dari kemegahan suatu bangsa.

\section{Mandat Untuk "namamu masyhur"}

Berkat menerima "nama yang masyhur atau besar" gadol syemekha (ayat 2c) merupakan sebuah penghormatan bagi Abraham. Konteks masyarakat kuno menganggap nama masyhur sama dengan "popularitas" atau "penghormatan". Dalam sebuah monarki, kebesaran kerajaan ditentukan oleh nama besar atau nama mashyur seorang raja. Berkat Abraham ini sama sekali bertolak belakang dengan upaya manusia mencari nama melalui pembangunan menara Babel (11:1-9). Para pembangun menara Babel sebagai wujud penolakan terhadap perintah untuk pergi memenuhi bumi (Kej 1:28). Pembangunan itu bertujuan membangun kota agar mereka tidak terserak (11:4). Sementara mandate Abraham rela diserakkan dengan meninggalkan keluarganya, negeri dan bangsanya. Kemashyuran nama Abraham itu diperlihatkan dalam perubahan penyebutan nama "Abram" menjadi “Abraham" bapa banyak bangsa/as "father" by a host of peoples (Kej.17:5-6). Kemashyuran nama itu tampak ketika Abraham diberi gelar "nenek moyang” atau "bapa leluhur orang percaya" (Kej 13:16; 15:5; 17:2 dst).

Karena ketaatannya menjalankan misi maka kegenapan bapa banyak bangsa mulai tampak dalam peneguhan perjanjian kepada Ishak (Kej. 26:3) dan Yakub (Kej. 28:13) yang kemudian diteruskan melalui keturunannya. Jauh setelah Abraham, secara historis bangsa besar itu dikukuhkan pada Daud dan pemerintahannya (2 Samuel 7:9b). Menurut Clause Westermann kata "bangsa” merupakan konsep politik, terkait erat 
dengan adanya wilayah, bahasa dan pemerintahan. Frase "nama masyhur" merupakan atribut raja di Perjanjian Lama. Selanjutnya, "nama masyhur" dikaitkan dengan wilayah kekuasaan. Oleh karena itu, janji pemberian tanah Kanaan adalah sebagai warisan yang diberikan Allah bagi Abraham dan keturunannya. Maka perebutan tanah itu dilakukan dengan perang suci kherem, yaitu sesuatu yang dikhususkan bagi Allah (Yos 6:17, 24; 8:24-29). Tentu saja, mandat misi untuk mendapatkan tanah perjanjian itu, tidak diberikan Allah secara langsung, melainkan dengan usaha dan merebutnya dari bangsa Kanaan.

\section{Mandat Untuk "engkau akan menjadi berkat"}

Abraham dipanggil menjadi mediator berkat. Janji berkat bagi Abraham diwujudkan melalui pelaksanaan tugasnya sebagai mediator berkat bagi bangsabangsa.(Tennent, 2010) Abraham merespon panggilannya dengan iman yang kokoh dan ketaatan penuh. Berkat Abraham sebagai bangsa yang besar, diberkati secara pribadi, dan namanya masyhur bertujuan agar ia menjadi berkat, dan olehmu seтиa kaum di muka bumi akan mendapat berkat. Kata kerja barakh "berkat" menunjukkan bahwa Allah sendiri sebagai pemberi hidup yang memberkati Abraham sehingga ia memiliki hidup yang dipenuhi kuasa, makmur dan berkualitas. Dalam narasi Patriakh, Allah memberi berkat materi, berkat spiritual dan sosial. Berkat Abraham itu juga diakui bangsa-bangsa kafir (Kejadian 21:22-23; 26:28-29; 30:30; 39:2-5, 21; 47:10). Abraham diutus untuk berdoa sehingga Abimelekh dan penduduk Gerar terhindar dari penghukuman Allah (20:17-18). Ishak dilepaskan dari tangan Abimelek agar menjadi berkat bagi Abimelek.

Abraham menjadi representasi kerajaan Allah, oleh kehadirannya ia memerintah dan berkuasa atas namaNya, sebagai perantara kerajaan Allah. Jadi tampak jelas bahwa pelaksanaan mandat misi dilakukannya dari diri sendiri, keluarga, umat dan bangsabangsa.

\section{Pembebasan Umat Allah Sebagai Mandat Misi}

Pandangan Alkitab terhadap pembebasan dilatarbelakangi pemikiran penahanan dalam penjara atau perbudakan (Kej. 39:20; Mzm. 105:20; Kis. 26:32). Pembebasan memiliki pengertian teologis yang berkembang sehingga menjadi pokok 
tersendiri dalam hidup umat Israel. Keyakinan Israel terhadap pembebasan adalah sebagai anugerah Tuhan dimana hal itu terlihat secara jelas dalam kemerdekaannya dari dominasi bangsa-bangsa asing.Penempatan peristiwa keluar dari Mesir merupakan pokok penting dalam kepercayaan Israel tampak dari formula "Akulah Tuhan yang membawa engkau keluar dari tanah Mesir, dari rumah perbudakan.” Rumusan pengakuan iman Israel yang sudah baku, seperti tampak dalam pendahuluan Dekalog (Kel. 20:2; Ul. 5:6; Mzm. 81:10, Am. 2:10, Yer. 2:6).

\section{Musa Mandataris Misi}

Peran penting Musa dalam peristiwa pembebasan merupakan kesaksian bahwa ia menjadi istrumen penting dalam misi itu. Misi penting dalam pokok itu, antara lain: pertama, pembebasan adalah hak setiap orang. Kemerdekaaan merupakan hak yang paling asasi dari seorang manusia. Peristiwa pembebasan Mesir dipandang bukan sekedar keluar dari satu tempat ke tempat lain melainkan pembebasan Israel dari perbudakan Mesir (Kel. 6:5). Mesir sebagai "rumah perbudakan” tempat pengeksploitasian manusia dengan kerja keras, tidak peduli dengan upah dan hak-hak manusia pekerja, pembuhuhan anak-anak lelaki Israel, tidak ada kebebasan beribadah (Kel. 1:13, 14).(David Hinson, 2004) Rupanya, pembebasan Israel dari Mesir bukan semata-mata pembebasan fisik saja melainkan juga pembebasan secara rohani yaitu pembebasan dari ketakutan terhadap ilah-ilah Mesir (Kel. 14:10). Pembebasan itu melepaskan segala keterikatan baik politik, ekonomi, sosial, dan spiritual.(Wright, 2013) Respon terhadap kemerdekaan itu tampak dalam pembacaan Keluaran 1-5 pada masa Paskah, sebagai pokok penting di dalam puji-pujian Israel (Mzm. 66:6; 77:20-21; $78: 12-13 ; 136: 10-12)$.

Kedua, misi pembebasan adalah inisiatif Allah. Dengan kekuatannya Israel tidak dapat melepaskan dirinya sendiri dari kekuasaan Mesir. Allah sendirilah yang memiliki inisiatif untuk kemerdekaan Israel itu (Kel. 3-12). Oleh kemahakuasaanNya, melalui tindakan-tindakan ajaib dalam kesepuluh tulah telah menaklukkan Firaun. Diperlihatkan kekalahan kuasa-kuasa di Mesir, termasuk kuasa kegelapan yang dikendalikan Firaun (Kel. 4:22-23).(Barth, 1984) Dalam pembebasan, natsal Israel, Allah menebus umatNya (Kel. 3:8; 18:4; 8-10; Hak. 6:9; 1 Sam. 10:18). Kata lain adalah gaal dan pada, yang digunakan untuk menebus seorang budak dengan harga tebusan. Kematian anak 
sulung di Mesir merupakan harga mahal yang harus dibayarkan untuk kelepasan umat Allah itu. Di sinilah Israel terhisabkan sebagai anggota keluarga Allah; di mana Allah sendirilah yang menjadi Bapa mereka yang akan menjaga dan melindunginya.(Barth, 1984)

Ketiga, pemilihan dan pengangkatan Israel sebagai umat Allah. Proklamasi kebebasan Israel dari perbudakan Mesir bertujuan untuk pemilihannya sebagai anak Allah sendiri. Secara implisit gagasan tentang umat sudah dimulai ketika Allah memanggil para leluhur Israel namun secara eksplisit dinyatakan melalui peristiwa keluaran (Kel. 3:17; 5:1; 6:6; 7:16; Ul. 7:6-8). Pembebasan menjadikan Israel sebagai anak sulung Allah, Israel ialah anak-Ku, anak-Ku yang sulung (Kel. 4:22). Penyebutan anak sulung mengindikasikan Israel mendapat tempat yang khusus di hadapan Allah. Tujuan pemilihan Israel situ agar mereka beribadah kepadaNya (Kel. 4:23). Selanjutnya umat Israel menyandarkan seluruh hidup dan kepercayaannya hanya kepada Tuhan saja (Kel. 14:31).

Keempat, terhisab dalam ikatan perjanjian. Israel adalah umat yang terhisab ke dalam suatu perjanjian dengan TUHAN Allah. Masuknya Israel ke dalam ikatan perjanjian itu dinyatakan di Sinai.(Barth, 1984) Dalam ikatan perjanjian itu pula Israel menjadi harta kesayangan Tuhan, kerajaan imam dan bangsa yang kudus (Kel. 19:5-6). Umat yang terhisab ke dalam satu persekutuan yang dilandasi atas perjanjian serta terikat dengan ketetapan dan peraturan bagi mereka di Sinai. Realitas dan identitas Israel sebagai umat Allah dalam Perjanjian Lama semakin hari berkembang dari individu, keluarga, hingga menjadi bangsa.(Kraus, 1993).

\section{Mandat Israel Sebagai Umat Allah}

Salah satu pokok penting dalam proses pembentukan di padang gurun adalah pengikatan perjanjian di Sinai, yang menjadikan Israel sebagai umat Allah sendiri, yang dipilih dalam kasih berdasarkan kedaulatan Allah untuk menerima keselamatan dan pengangkatan umat sebagai anak-anak Allah. Umat yang kudus yang olehnya keselamatan juga dinyatakan kepada bangsa-bangsa.(Merrill, 1996) Allah yang universal menjadi Allah yang etnosentrisme Israel.(Ruck, 2011) Esensi umat Allah sebagai komunitas yang terikat dengan komunitas ilahi, sehingga segala sesuatu tergerak dan termobilisasi untuk misional ilahi.(Ruck, 2011) 
Beberapa pokok penting dalam misi Israel sebagai umat Allah terlihat dalam hal:

\section{Menjadi“"Harta Kesayangan"}

Menjadikan Israel sebagai "harta kesayangan" segulla setelah pembebasan dari Mesir adalah hak prerogatif Allah sendiri (U1. 7:6). Harta kesayangan menunjukkan relasi yang sangat khusus dalam wujud kepedulian Allah bagi umatNya (Kel. 19:5-6; 24:7-8).(Wright, 2013) Unsur-unsur penting dalam menjadikan Israel sebagai harta kesayangan antara lain: pertama, sifat kasih karunia dalam perjanjian di Sinai sama dengan perjanjian dengan Abraham (Kej. 17:9-14; 18:18, 19). Kedua, hubungan yang diikat itu seperti relasi bapa dengan anak, sehingga umat yang diangkat menjadi anak itu menampilkan hidup dalam kekudusan Allah. Ketiga, kekudusan menjadi segi integral dari berkat perjanjian. Kekudusan sebagai syarat penting bagi kesinambungan berkatberkatnya.(Walter Kaiser, 2008) Israel telah diselamatkan untuk menjadi umat yang kudus, yang dipisahkan bagi Tuhan. Kekudusan itu secara konkrit dilukiskan dalam ketaatan kepada perjanjian. Keempat, Allah sendiri sebagai penggagas perjanjian. Allah adalah inisiator perjanjian, yang mengikatkan diri-Nya dengan Israel (Kel. 19:5, 6; 24:7, 8). Allah datang terlebih dahulu, memberikan iman kepada umat dan diresponi dengan ketaatan.(Wright, 2013) Oleh sebab itu dalam menaati perjanjian dan firman Allah (Kel. 24:7) respon umat terhadap kasih karunia sangatlah penting.

\section{2. "Kerajaan Imam"}

Imam memiliki tugas penting yakni mengajarkan hukum Taurat dan menjadi perantara umat mempersembahkan korban kepada Allah.(Wright, 2013) Penyebutan "kerajaan imam" mamlekhet kokhanim atau "imamat rajani" merupakan ikatan perjanjian di Sinai. Panggilan khusus umat Allah itu telah diproklamirkan bersama oleh Musa dalam perjanjian Sinai (Kel. 19:3-6). Menjadi kerajaan imam terhubung dengan pemanggilan nenek moyang mereka yakni Abraham, Ishak dan Yakub yang juga bertugas sebagai mediator berkat bagi bangsa-bangsa (Kej. 12:1-3). Perjanjian dalam keluarga kini berkembang menjadi perjanjian dengan sebuah bangsa.(Walter Kaiser, 2008)

Pemilihan Israel yang khusus dan istimewa menjadikannya kerajaan imam” (U1. 7:6-7), adalah kasih Allah yang berdaulat.(Forbers, 2010) Jadi bukan tindakan sewenang-wenang Allah atau pemilihan tanpa memperhatikan asas-asas keadilan. 
Pertama, pemilihan adalah tindakan Allah yang bebas dan berdaulat yang tidak terikat oleh apapun dan siapapun. Pemilihan merupakan hak prerogatif Allah sendiri yang dilandaskan dengan kasih-Nya yang bebas (Mal. 1:2-3). Jadi Allah memilih Israel karena Allah mau memilih mereka atas kehendak-Nya. Kedua, Allah memilih Israel dengan bebas bukan merupakan kesewenangan yang menakutkan, sehingga Israel dapat bertindak atas kehendaknya sendiri. Tindakan Allah untuk memilih Israel agar ia menjadi saksi demi keselamatan dunia ini (Kej 12:1-3; Yes 49:6). Ketiga, pemilihan Israel sebagai umat Allah untuk mengemban tugas sebagai pembawa terang dan keselamatan bagi dunia ini sekaligus pula menjaga dan mempertahankan identias dirinya (U1 6:5; Im 19:18; Luk 12:48). Dengan demikian imamat umat Allah merupakan fungsi misionalnya yang diwarisi dari panggilan Abraham yang berdampak bagi bangsa-bangsa.(Wright, 2013)

\section{3. "Bangsa yang kudus"}

Istilah "bangsa yang kudus" merupakan sebutan yang sangat penting di Israel, yang menunjukkan bagaimana "orang yang dipisahkan”, "dikhususkan” atau “diistimewakan dari yang lain” untuk tujuan atau tugas tertentu.(Ruck, 2011) Pertama, kekudusan merupakan karakteristik yang harus melekat pada Israel sebagai umat Allah. Di sini, nilai Israel sebagai harta kepunyaan Allah berfungsi sebagai kerajaan imam yang kudus. Kekudusan itu diresponi dengan ketatan terhadap pemeliharaan perjanjian, sebagaimana telah diikat dengan nenek moyang mereka. Mengabdi kepada Allah yang kudus menjadi panggilan hidupnya (Bnd. Kej. 17:9-14; 18:18, 19). Kedua, kekudusan selalu dilihat sebagai hubungan yang harmonis antara Allah dengan umatNya. Panggilan untuk hidup kudus adalah karena Allah sang pemilik Israel itu sendiri adalah kudus (Im. 19:2).(Forbers, 2010) Ketiga, kekudusan menjadi bagian integral dari berkat perjanjian Israel dengan Tuhan (Im. 20:26). Kekudusan secara konkrit dilukiskan dalam ketaatan dan kerelaan menjadi alat melalui mana persekutuan perjanjian terus menerus memberikan berkat-berkatnya.(Walter Kaiser, 2008) Keempat, kekudusan adalah anugerah dari Allah. Merupakan sebuah pandangan yang keliru bila ada yang menganggap bahwa ketaatan dilakukan lebih dahulu barulah Tuhan mengikatkan diri dalam Perjanjian Sinai itu (Kel. 19:5, 6; 24:7, 8).

Penekankan tentang keistimewaan "umat kepunyaan Allah" adalah keseriusan Israel merespon panggilan itu. Sebagai milik Allah, Israel dipanggil menjadi saksi untuk 
membangun kepujian bagi namaNya. Tujuan utama sebagai saksi membawa kabar keselamatan bagi bangsa-bangsa.

\section{SIMPULAN}

Dari pemaparan di atas terlihat bahwa karakteristik misi keluarga dan umat Allah dalam perjanjian Lama terkonsentrasi pada Allah sendirilah pusat misi. Allah yang mengutus dan menjadi keberlangsungan misiNya. Pengutusan misi agar menjadi agen berkat bagi bangsa-bangsa. Sentral pemberitaan misi adalah berita pembebasan. Orang yang sudah terhisab dalam pemilihan dijadikan umat Allah. Komunitas umat Allah itu menjadi kerajaan imam yang hidupnya terpelihara didalam kekudusan. Komunitas umat Allah itu melayani sebagai ibadatnya kepada Tuhan.

\section{DAFTAR PUSTAKA}

Balz, H. (2000). Exegetical Dictionary of The New Testament. Michigan: William B. Eerdmanns Publisher.

Barth, C. (1984). Teologi Perjanjian Lama 1. Jakarta: BPK Gunung Mulia.

David Bosch. (2006). Transformasi Misi Kristen:Sejarah Teologi Misi Yang Mengubah Dan Berubah. Jakarta: BPK Gunung Mulia.

David Hinson. (2004). Sejarah Israel Pada Zaman Alkitab. Jakarta: BPK Gunung Mulia.

Erich Sauer. (2001). The King of Earth: The Nobility of Man Acording To The Bible and Science. California: Createspace Independent Publisher.

Forbers, G. W. (2010). 1 Peter : Asia Bible Commentary Series. Manila: OMF Literature.

George Barna. (2018). Half Churchgoers Not Heard Great Commission.

Gerhard F. Hasel. (1989). Old Testament Theology: Basic Issues in Current Debate. Grand Rapids: William B. Eerdmanns Publisher.

Greatness, F. E. (1990). The Expository's Bible Commentary: Genesis, Exodus, Leviticus, Numbers. Grand Rapids: Zondervan Publishing House.

Haddon A. Haynes. (1994). The Pastor And His Family. Fellowship For Reformation and Pastoral Studies, 31, 111.

John Stott. (2007). Misi Menurut Perspektif Alkitab:Dasar dan Prinsip Penginjilan Sedunia. Jakarta: Yayasan Komunikasi Bina Kasih.

Kenneth A. Matthews. (2005). The New American Commentary Vol I Genesis 11:27 50:26. Nashville: Broadman \& Holman Publisher.

Kraus, J. . (1993). Umat Allah Dalam Perjanjian Lama. Jakarta: BPK Gunung Mulia. 
Menzies, W. W. (1998). Doktrin Alkitab. Malang: Gandum Mas.

Merril F. Unger. (1980). Nelson's Dictionary Of The Old Testament. Nashville: Thomas Nelson Publisher.

Merrill, E. (1996). Kingdom of Priest:A History of Old Testament Israel. Grand Rapids: Baker Book.

Merrill, E. (2015). Teologi Pentateukh. In Roy B. Zuck (Ed.), A Biblical Theology Of The Old Testament (pp. 51-54). Malang: Gandum Mas.

Paul Enns. (2008). The Moody Handbook of Theology. Chicago: Moddy Publisher.

Pentury, T. (2019). Generasi Milenial Kristen Tinggalkan gereja.

Ruck, J. R. \& A. (2011). Jemaat Misioner:Membawa Kabar Baik Dalam Masyarakat Majemuk Abad XXI. Jakarta: Yayayan Komunikasi Bina Kasih.

Strong, J. (2007). Strong's Exhaustive Concordance of The Bible. Iowa: Riverside Book And Bible House.

Tennent, T. C. (2010). Invitation To World Mission: A Trinitarian Missiology for The Twenty-First Century. Grand Rapids: Kregel.

Tomatala, Y. (2003). Penginjilan Masa Kini. Jakarta: YT Leadership Foundation.

Wallace, R. . (1997). Manusia. In Ensiklopedia Alkitab Masa Kini (p. 25). Yayasan Komunikasi Bina Kasih.

Walter C. Kaiser. (2000). Mission in The Old Testament: Israel As A Light To The Nation. Grand Rapids: Baker Book.

Walter C. Kaiser. (2004). Teologi Perjanjian Lama. Malang: Gandum Mas.

Walter Kaiser. (2008). The Promised Plan Of God: A Biblical Theology of The Old and New Testament. Grand Rapids: Zondervan Publishing House.

Wright, C. J. . (2007). The Mission of God:Unlocking The Bible's Grand Narrative. Illinois: IVP and Nothingham.

Wright, C. J. . (2013). Misi Umat Allah: Sebuah Teologi Biblika Tentang Misi Gereja. Jakarta: Perkantas. 